\title{
Liquid Streptomyces Solubles and Condensed Molasses Solubles as Feed Supplements for Cows at Pasture ${ }^{1,2}$
}

\author{
Jack A. Korber and Paul F. Randel ${ }^{3}$
}

\begin{abstract}
On the basis of the lactational, partial feed conversion and liveweight responses observed, LSS and SCM are judged satisfactory as liquid supplements in partial substitution for concentrates for cows at pasture. However, their animal acceptance is suboptimal.

Four groups of 7 cows each, some Holstein and some Brown Swiss were used in an experiment for two 5-week periods, to test four treatments in a design consisting of two single reversals of treatments. Treatments A, LSS supplementation, and B, a control, were tested in a Latin square design; and C, CMS supplementation, and D, a control, were tested in a similar design. Dally individual concentrate allowances were reduced by an amount equivalent in dry matter (DM) to that consumed in liquid supplements in treatments $A$ and $C$. These were offered free choice to cows in groups for 5 or 6 hours daily. At night all cows grazed together in fair quality pastures. Over-all means and SD were as follows: deily milk production, $11.25 \pm 4.05 \mathrm{~kg}$; milk fat, 3.67 $\pm .66 \%$; milk solids not fat (SNF), $8.79 \pm .61 \%$; milk total solids (TS), 12.46 $\pm .98 \%$. Treatments had no significant effects on these characteristics. LSS consumption did not result in detectable antibiotic activity in the milk. Daily consumptions of DM from LSS in periods 1 and 2 and overall were $.64, .18$ and $.41 \mathrm{~kg}$, respectively. Corresponding flgures for CMS were $.44,1.36$ and $.89 \mathrm{~kg}$. Ratios of milk and of fat corrected milk (FCM) produced/total supplemental DM consumed were as follows in the four treatments: $A, 4.15$ and $4.10 ; B, 4.03$ and $3.81 ; C, 3.74$ and $3.47 ; D, 3.77$ and 3.51 .
\end{abstract}

\section{INTRODUCTION}

Liquid streptomyces solubles (LSS) is a stable byproduct of the manufacture of erythromycin by a pharmaceutical company located in Barceloneta, Puerto Rico. Annual production thereof exceeds 20,000 tons, most of which is exported to the United States for use in broiler feeds (1). Interest on the part of the manufacturer in marketing this byproduct locally, as a liquid feed supplement for cattle, was one motivation for the present investigation.

Another local byproduct is molasses distiller's slops or stillage. In partially dehydrated form, condensed molasses solubles (CMS), this material is stable and has been used to some extent as cattle feed in other countries (6). However, most of the stillage generated by the four rum distilleries operating in Puerto Rico is discharged into the ocean, resulting

' Manuscript submitted to Editorial Board July 13, 1981.

${ }^{2}$ Data taken from a thesis by the senior author in partial fulfillment of the requirements for the degree of Master of Science. Mayagüez Campus, U.P.R. May, 1981.

${ }^{3}$ Formerly graduate student in Department of Animal Science, Mayagüez Campus, U.P.R., presently Agricultural Credit Agent, Puerto Rican Department of Agriculture; and Animal Nutritionist, Agricultural Experiment Station, U.P.R., Lajas, respectively. 
in environmental pollution. The need to find a non-polluting method of disposal for stillage and the possibility that CMS might be a useful feed resource motivated this second aspect of the present study.

\section{MATERIALS AND METHODS}

The experiment employed two periods and four groups of animals. The four treatments studied involved liquid supplementation with either LSS (A) or CMS (C), tested against respective control treatments (B and D). The design consisted of two single reversals of treatments (or $2 \times 2$ Latin squares) in parallel, i.e., treatments $\mathrm{A}$ and $\mathrm{B}$ in square 1 and $\mathrm{C}$ and $\mathrm{D}$ in square 2, Each experimental group consisted of 7 cows, some Holstein and some Brown Swiss. These were divided into quartets as homogeneous as possible in m:lk production and stage of lactation. From each quartet one cow was assigned at random to each experimental group.

Each period lasted 5 weeks altogether, subdivided as follows: 4 days for adaptation, 10 days for equilibration of supplemental feeding and 21 days for comparison of treatments.

Concentrates were fed individually to the cows in stanchions after AM milking. Thereafter, the groups assigned to treatments $\mathrm{A}$ and $\mathrm{C}$ were moved, one to each half of an exercise lot with Saran shade, where they had access ad libitum to their respective liquid supplements until PM milking: Meanwhile the cows of treatments B and D were kept together in an adjacent lot without liquid supplement. After PM milking the cows of all groups grazed together until AM milking of the following day. Daily concentrate allowances were equal to $1 \mathrm{~kg}$ per $2 \mathrm{~kg}$ of milk produced beyond the first $5 \mathrm{~kg}$. Those of treatment $\mathrm{A}$ and $\mathrm{C}$ cows were reduced by an amount equivalent in dry matter (DM) to liquid supplement intakes. Readjustment for changes in milk production and LSS or CMS intakes was at 5-day and 7-day intervals during the equilibration and comparison periods, respectively. The concentrate mixture was a commercial product with $18 \%$ guaranteed minimum crude protein, composed of ground yellow corn, cottonseed meal, wheat middlings, hominy, cane molasses, alfalfa meal, calcium carbonate, salt and supplements of micronutrients.

Sixteen paddocks, ranging in size from .90 to $3.83 \mathrm{ha}$, with a total area of 34.48 ha, were used for grazing during the 10 weeks of experimentation, from 31 October 1977 to 7 January 1978 . The paddocks varied greatly in botanical composition, the principal improved species being stargrass (Cynodon nlemfluensis), pangolagrass (Digitaria decumbens Stent), guineagrass (Panicum maximum Jacq.), and paragrass (Brachiaria purpurascens (Raddi) Henr.). Spontaneous vegetation was present to varying degrees in different paddocks and included notably the grass Andropogon annulatus. Fertilizer of formula 15-5-10 was applied 16 to 18 November at an average rate of $764 \mathrm{~kg} / \mathrm{ha}$ to 9 paddocks comprising 20.54 ha. 
Rainfall during the first 2 weeks of the experiment was $154 \mathrm{~mm}$, but only $26 \mathrm{~mm}$ was recorded during the remaining 8 weeks. Therefore, soil moisture was suboptimal during the latter part of the experiment. Pasture herbage quantity and quality, assessed subjectively at the start, was judged adequate for maintenance and production of $5 \mathrm{~kg}$ of milk daily. This assumption was maintained throughout, although it may have been an overestimate of pasture capabilities during the latter stages.

Aliquot milk samples from the last four milkings of each cow in both comparison periods were analyzed for total solids content by oven drying at $98-100^{\circ} \mathrm{C}$, for fat percentage by the T.E.S.A. procedure (8) and for antibiotic activity (3). Samples of the concentrate mixture and liquid supplements were oven dried at $65^{\circ} \mathrm{C}$ for DM determination and analyzed for crude protein (CP), crude fiber and ash (2).

Analysis of variance was used to analyze the milk production and milk composition data. The 55 total degrees of freedom were subdivided as follows: squares, 1 ; groups within squares, 2 ; periods, 1 ; squares $\mathrm{x}$ periods, 1; treatments, 2; cows within groups within squares, 24; and residual, 24. Confounding of treatments and squares caused the reduction in degrees of freedom for treatments from 3 to 2 . In effect, the comparison of squares is the same as the comparison of treatments $\mathrm{A}+\mathrm{B}$ vs. $\mathrm{C}+\mathrm{D}$.

TABLE 1.-Pencentage chemical composition of supplemental feeds determined in each period

\begin{tabular}{|c|c|c|c|c|c|c|}
\hline \multirow[b]{2}{*}{ ? } & \multicolumn{2}{|c|}{$\begin{array}{l}\text { Conmercial } \\
\text { concentrate }\end{array}$} & \multicolumn{2}{|c|}{ I.SS } & \multicolumn{2}{|c|}{ CMS } \\
\hline & $\begin{array}{c}\text { Period } \\
I\end{array}$ & $\begin{array}{c}\text { Period } \\
2 \\
\end{array}$ & $\begin{array}{c}\text { Period } \\
1\end{array}$ & $\begin{array}{c}\text { Period } \\
2\end{array}$ & $\begin{array}{c}\text { Period } \\
1\end{array}$ & $\begin{array}{c}\text { Period } \\
\mathbf{2} \\
\end{array}$ \\
\hline Dry matter & 89.0 & 92.7 & 29.3 & 29.8 & 51.4 & 53.0 \\
\hline Crude protein ${ }^{1}$ & 20.3 & 18.6 & 22.4 & 23.9 & 7.8 & 7.9 \\
\hline Crude fiber' & 5.3 & 6.5 & .7 & .9 & 4 & .4 \\
\hline Ash' $^{\prime}$ & 10.9 & 9.3 & 36.0 & 38.3 & 30.8 & 36.3 \\
\hline
\end{tabular}

${ }^{1}$ Dry basis.

\section{RESULTS AND DISCUSSION}

Table 1 shows the data on the chemical composition of the supplemental feeds. The CMS was somewhat more than 50\% DM, whereas the LSS was just below $30 \%$. The DM of these two supplements included very high proportions of ash, very little fiber, and high CP in LSS, but relatively low $\mathrm{CP}$ in CMS. The concentrate exceeded its guarantee of $18 \%$ $\mathrm{CP}$ as fed.

Daily milk production averaged $11.23 \mathrm{~kg}$ per cow for the entire experiment over-all. It decreased $(P=.01)$ from $11.66 \mathrm{~kg}$ in period 1 to $10.80 \mathrm{~kg}$ in period 2 and varied $(\mathrm{P}=.01)$ among individual cows. The minimum value per cow-period was $5.54 \mathrm{~kg}$ and the maximum $24.20 \mathrm{~kg}$. None of the 
remaining factors included in the analysis of variance significantly affected milk production. The means and standard deviations of the four treatments (table 2) indicate a slightly higher, but more variable production in Latin square 2 (CMS and control) than in Latin square 1 (LSS and control). Mean production was $11.59 \mathrm{~kg}$ in the former and $10.87 \mathrm{~kg}$ in the latter. Coeficients of variation within the four treatments ranged from $29.1 \%$ (A) to $41.7 \%$ (C). Both of the treatments employing liquid supplementation resulted in slightly lower production than their respective controls: LSS by $.38 \mathrm{~kg}$, and CMS by $.27 \mathrm{~kg}$.

Milk fat concentration averaged $3.67 \%$ over-all. The only factor which significantly $(\mathrm{P}=.05)$ affected this characteristic was the interaction of periods $\times$ squares. Square 1 mean was $3.93 \%$ in period 1 and $3.71 \%$ in period 2. Corresponding figures for Latin square 2 were $3.68 \%$ and $3.36 \%$. Square 1 mean exceeded that of square 2 by $0.30 \%$ over-all. Treatment $A$

TABLE 2.-Treatment means and standard deviations of daily milk yield and milk composition during the entire experiment

\begin{tabular}{|c|c|c|c|c|c|c|c|c|}
\hline & \multicolumn{2}{|c|}{$\underset{\text { LSS }}{A}$} & \multicolumn{2}{|c|}{$\begin{array}{c}B \\
\text { Control of } \\
\text { LSS }\end{array}$} & \multicolumn{2}{|c|}{$\begin{array}{c}\mathrm{C} \\
\mathrm{CMS}\end{array}$} & \multicolumn{2}{|c|}{$\begin{array}{c}\mathrm{D} \\
\text { Control of } \\
\text { CMS }\end{array}$} \\
\hline & Mean & SE & Mean & $S E$ & Mean & $\mathrm{SE}$ & Mean & SE \\
\hline Milk yield (kg) & 10.68 & 3.11 & 11.06 & 3.64 & 11.46 & 4.78 & 11.73 & 4.77 \\
\hline Milk fat $(\%)$ & 3.92 & .54 & 3.72 & .59 & 3.51 & .78 & 3.52 & .66 \\
\hline Milk solids-not-fat (\%) & 8.89 & .48 & 8.97 & .66 & 8.65 & .52 & 8.66 & .73 \\
\hline Milk total solids (\%) & 12.81 & .87 & 12,69 & .99 & 12.16 & 1.12 & 12.18 & .84 \\
\hline
\end{tabular}

(LSS) averaged $0.20 \%$ higher than its control, whereas treatment C (CMS) and its control had nearly identical mean fat percentages (table 2). Coefficients of variation within treatments ranged from $13.8 \%$ (A) to $22.2 \%$ (C).

Among the data for milk SNF and TS concentrations, there was one pair of unreasonable values from one cow in period 1 on treatment B. It was decided to substitute for these the values from the same animal in period 2, while reducing the degrees of freedom by 1 . Over-all means were then $8.79 \% \mathrm{SNF}$ and $12.46 \% \mathrm{TS}$. None of the factors analyzed significantly affected the SNF $(\mathrm{P}=.05)$, while the TS was affected $(\mathrm{P}=.05)$ by the interaction of periods $\times$ squares and by the variation among individual cows. Square 1 gave TS means of $12.91 \%$ and $12.59 \%$ and square $2,12.23 \%$ and $12.11 \%$ in periods 1 and 2, respectively. Ranges among individual cow-periods were $6.96 \%$ to $10.27 \%$ in SNF and $10.44 \%$ to $14.19 \%$ in TS. Coefficients of variation for individual treatments ranged from $5.40 \%$ (A) to $8.43 \%$ (D) in the former, and from $6.8 \%$ (A) to $9.2 \%$ (C) in the latter. Treatments $\mathrm{A}$ and $\mathrm{C}$ averaged $.08 \%$ and $.01 \%$ lower SNF than their 
respective controls; treatment $\mathrm{A}$ exceeded its control in TS by $.12 \%$, but $\mathrm{C}$ was $0.02 \%$ below its control (table 2 ).

All of the milk samples gave negative results to the test for the presence of antibiotic activity.

Liveweights $(\mathrm{kg})$, determined at the completion of each comparison period, gave the following means and standard deviations: $467 \pm 2.8$ and $477 \pm .7$ for the two groups of cows in square $1,472 \pm 4.9$ and $508 \pm 1.1$ for those in square 2; and 483 over-all. Means for the respective treatments ( $A$ to $D$ ) were $472 \pm 9.2,473 \pm 5.7,493 \pm 20.5$ and $497 \pm 16.9$.

A marked difference was observed between periods 1 and 2 in voluntary consumption of the liquid supplements. In period $1,2.21 \mathrm{~kg}$ of LSS was consumed per head daily (equivalent to $.64 \mathrm{~kg} \mathrm{DM}$ ), whereas consumption of CMS was less, .86 in liquid form or $.44 \mathrm{~kg}$ DM. By contrast, in period 2 only .61 kg of LSS was consumed (.18 kg DM), compared to $2.56 \mathrm{~kg}$ of CMS (1.36 kg DM). Means for the entire experiment were: LSS, $1.41 \mathrm{~kg}$

TABLE 3.-Daily intakes ( $\mathrm{kg}$ ) of dry matter from supplemental feeds and partial feed conversion ratios of supplemental dry matter into milh and fat-corrected-milh

\begin{tabular}{cccccc}
\hline Treatment & $\begin{array}{c}\text { DM from } \\
\text { concentrates }\end{array}$ & $\begin{array}{c}\text { DM from } \\
\text { liquid supple- } \\
\text { ment }\end{array}$ & $\begin{array}{c}\text { Total supple- } \\
\text { ment DM }\end{array}$ & $\begin{array}{c}\text { Milk supple- } \\
\text { ment DM }\end{array}$ & $\begin{array}{c}\text { FCM supple- } \\
\text { ment DM }\end{array}$ \\
\hline A & 2.16 & -41 & 2.57 & 4.15 & 4.10 \\
B & 2.74 & - & 2.74 & 4.03 & 3.81 \\
C & 2.17 & .89 & 3.06 & 3.74 & 3.47 \\
D & 3.11 & - & 3.11 & 3.77 & 3.51 \\
\hline
\end{tabular}

liquid and .41 kg DM (table 3); CMS, $1.71 \mathrm{~kg}$ liquid and $89 \mathrm{~kg}$ DM (table 3). LSS contributed $16 \%$ of the total DM from supplements in treatment A, while CMS contributed $29 \%$ in treatment C.

There was $.58 \mathrm{~kg}$ less intake of DM from concentrates and $.20 \mathrm{~kg}$ less total DM from supplements in treatment A (LSS) than in its control, (table 3). The former gave higher production of milk and $4 \%$ fat-correctedmilk (FCM) per unit of total supplemental DM, 4.15 vs. 4.03 and 4.10 vs. 3.81 , respectively (table 3). In comparing treatments $C$ and $D, C M S$ supplementation was associated with $.94 \mathrm{~kg}$ and $.05 \mathrm{~kg}$ less consumption of DM from concentrates and from total supplements, respectively, relative to the control (table 3 ). Partial feed conversion ratios were slightly less favorable with CMS supplementation by margins of .03 for milk and .04 for FCM productions (table 3).

The results demonstrate that LSS and CMS as free choice liquid offerings in partial substitution for concentrates, as nearly as possible on the basis of DM equivalencies, did not have important adverse effects on milk production or composition, liveweight or efficiency of utilization of 
supplemental DM for lactation. Possible contamination of the milk of cows consuming LSS with antibiotic activity was shown not to be a problem. Voluntary consumption of these two liquid supplements varied appreciably between different groups of cows, but generally should not be expected to exceed $1 \mathrm{~kg}$ of DM per head daily. Animal acceptance of both liquids studied could probably benefit from their inclusion in mixtures with other high-palatability feeds, such as cane molasses.

Other studies support this contention. A mixture of $70 \%$ LSS and $30 \%$ cane molasses was accepted extremely well by dairy cattle and showed a high digestible energy content (7). CMS in a $3: 1$ combination with cane molasses was consumed in considerably greater quantity than pure CMS and was efficiently utilized by lactating cows (5). Both the study just cited and research in Florida (4) have revealed that different lots of CMS vary in animal acceptance and nutritive value.

\section{RESUMEN}

Cuatro grupos de 7 vacas, algunas Hoistein y otras Pardo Suiza, cada uno, se utilizaron en un experimento de dos períodos para probar cuatro tratamientos, en un diseño que constó de dos reversiones simples de tratamientos. Los tratamientos $A$, suplementación con fracciones solubles de estreptomicetos (LSS), y B, un testigo, se alternaron en un diseño de cuadrado latino; tratamientos $C$, suplementación con fracciones solubles condensadas de la destilación de melaza de caña de azúcar (CMS), y D, otro testigo, se alternaron en un diseño similar. Se redujeron las asignaciones diarias de concentrado por una cantidad equivalente en materia seca (DM) a la consumida en los suplementos líquidos en los tratamientos $A$ y $C$. Estos se ofrecieron a las vacas en grupos por 5 ó 6 horas diarias. De noche todas las vacas pastaron juntas en praderas de mediana calidad.

Se obtuvieron los promedios globales (y desviaciones estándares) siguientes: producción lechera diaria, $11.23 \pm 4.05 \mathrm{~kg}$; grasa láctea, $3.67 \pm .66 \%$; sólidos no grasos lácteos, $8.79 \pm .61 \%$; sólidos totales lácteos, $12.46 \pm .98 \%$. Los tratamientos no tuvienon influencia significativa sobre estas características. El consumo de LSS no resultó en actividad antibiótica detectable en la leche. Los consumos diarios de DM procedente de LSS en los períodos 1 y 2 y en total fueron $.64, .18$ y .41 $\mathrm{kg}$, respectivamente. Las cifras correspondientes para CMS fueron .44, 1.36 y $.89 \mathrm{~kg}$. Los cocientes de leche o leche corregida a $4 \%$ de grasa producida/DM suplementaria total consumida fueron como sigue en los cuatro tratamientos: A, 4.15 y 4.10 ; B, 4.03 y 3.81 ; C, 3.74 y 3.47 ; D, 3.77 y 3.51 .

A base de los datos referentes a las lactancias, de conversión parcial de los alimentos y de peso vivo, se estiman al LSS y al CMS como 
suplementos liquidos satisfactorios en sustítución parcial de los concentrados para vacas a prado. Sin embargo, su aceptación no es muy buena.

\section{LITERATURE CITED}

1. Anonymous, 1976. Streptomyces Solids and Fermentation Solubles. Abbott Laboratories Agricultural and Veterinary Products Division, North Chicago, Illinois. p. $\$ 2$.

2. Association of Official Agricultural Chemists, 1960. Official Methods of Analysis, 9th ed, A.O.A.C., Washington, D.C.

3. Messer, J. W., L. L. Claypool, G. A. Houghtly, F. M. Mikolajcik and E. L. Sing, 1978. Detection of antibiotic residues in milk and dairy products. E.H. Marth (Ed). Standard Methods for the Examination of Dairy Products, 14th ed, American Public Health Association, Washington, D.C.

4. Moya, A. J., I981. Use of condensed molasses solubles, molasses and soybean meal as nitrogen and energy sources for ruminants, M.S. Thesis. University of Florida, Gainesville. p. 111 .

5. Randel, P. F., 1981. Suplementos líquidos con mosto condensado de destilería del ron para vacas lecheras, A.L.P.A. Mem. Publication pending.

6. Swa, W., 1973. A literature survey on molasses stillage for possible use in feedstuffs. ACD Project Rep. ORF 73-1, Part A. Ontario Research Foundation, Sheridan Park, Ontario.

7. Vallejo, B., 1980. Evaluación de solubles de estreptomicetos derivados de la producción de eritromicina y mosto condensado de la destilación de melaza de caña como suplementos líquidos para ganado lechero. M.S. Thesis. Mayaguez Campus, U.P.R. p. 75 .

8. Washburn, R. G., 1959. The new accurate butter fat test kit. Presented at Meet. of Milk Industry Foundation, Miami, Florida. Oct., 1959. 